\title{
Interactive comment on "Storm-induced sediment supply to coastal dunes on sand flats" by Filipe Galiforni-Silva et al.
}

Filipe Galiforni-Silva et al.

f.galifornisilva@utwente.nl

Received and published: 4 March 2020

Dear Prof. Dr. Edward Anthony,

Thank you very much for your time to review our manuscript. It was with much enthusiasm that we received such nice comments on our paper coming from a well-known expert in the theme. We have carefully revised the manuscript accordingly, and we give the responses to each comment below. Minor typo/grammatical points will be corrected in the revised version.

Minor comments

- Regarding the armouring effects discussed on page 20 , could therebe a salt-crusting effect too that contributes to armouring? (See reference 2 below) 
R: Indeed, salt-crusting may be a potential effect that contributes to the armouring. Of course, a definite idea of which process leads the armouring would require a dedicated

ESurfD study in the area. However, we believe that, regardless of the leading processes, the reworking of the top layer due to the storm surge would be enough to reduce the armouring and enhance supply to the dunes. The reference of this process will be added in the discussion part of the revised version.

Interactive

comment

Interactive comment on Earth Surf. Dynam. Discuss., https://doi.org/10.5194/esurf-2019-76, 2020. 